\title{
Highly Enantioselective Catalytic Asymmetric Synthesis of a $(R)$-Sibutramin Precursor
}

\author{
Ulrich Berens ${ }^{\star a}$, Andreas Hafner ${ }^{\star b}$, Oliver Dosenbach ${ }^{\mathrm{b}}$, Tanja Tritschler ${ }^{\mathrm{b}}$, Franz Schwarzenbach ${ }^{\mathrm{b}}$ \\ Hans-Jörg Kirnerb, Christophe Malanc, and Oanh Mai-Huynh
}

\section{Dedicated to Prof. Dr. Daniel Belluš on the occasion of his 70th birthday}

\begin{abstract}
The first highly enantioselective, catalytic asymmetric synthesis of di-des-methylsibutramine $\mathbf{3}$ is described. Dienamide 10, prepared by acetic acid anhydride quenching of the condensation product of nitrile 4 with a methallyl magnesium chloride, proved to be an excellent substrate for ruthenium-catalyzed asymmetric hydrogenation with atropisomeric diphosphine ligands. Hydrogenation with a ruthenium/(R)- MeOBiPheP catalyst at $\mathrm{S} / \mathrm{C}=500$, gave the chiral amide $(R)-9$ in $98.5 \%$ ee in almost quantitative yield. After acidic amide hydrolysis the desired amine (R)-3 was obtained without erosion of enantioselectivity. It is anticipated that the overall process will be amenable to large-scale production.
\end{abstract}

Keywords: Catalytic asymmetric hydrogenation $\cdot$ Enantioselective synthesis $\cdot$ Sibutramine

\section{Introduction}

At the turn of the Millennium Ciba Specialty Chemicals Corporate Research Organisation was pursuing New Business development projects, related to new production processes for the pharmaceutical industry, based on its core competences in the area of innovative synthesis design, enantioselective catalysis and control of physical properties of actives. During the course of these studies we have investigated the enantioselective synthesis of sibutramin.

Racemic sibutramine $\mathbf{1}$ is one of the few drugs which is licensed for the longterm treatment of obesity. ${ }^{[1]}$ On absorption, the drug is rapidly metabolized to give the primary metabolites des-methylsibutramine $\mathbf{2}$ and di-des-methylsibutramine 3 (Fig. 1). Preliminary preclinical studies suggest that the potent serotonin, norepinephrine, and dopamine re-uptake inhibitor
(R)-2 might be useful for the treatment of CNS disorders. ${ }^{[2]}$ Also, the enantiomers of $\mathbf{3}$ have been claimed for the treatment of depression and related disorders. ${ }^{[3]}$ The pharmaceutical profiles of 1-3 made these compounds an attractive target for both us and a group at Sepracor.

An efficient route to access any of compounds 1-3 with high enantiopurity allows the other compounds to obtain either via methylation or de-methylation chemistry. Resolution of racemic $\mathbf{1}$ with a chiral acid and de-methylation of the resolved 1 with diethyl-azodicarboxylate (DEAD) to give enantiopure 2 was studied at Sepracor. ${ }^{[4]}$ However, the risks of using DEAD, which can violently decompose, ruled this approach out for the production of commercial quantities of $\mathbf{2}$. As an alternative, a procedure for the resolution of $\mathbf{2}$ with chiral acids was developed, but the efficiency of the resolution was low. ${ }^{[5]}$ Therefore, a catalytic asymmetric synthesis of $(R)-2$ by the enantioselective addition of isobutyl lithium to imine 5 was developed (Scheme 1). This approach is potentially very attractive, but even with the best identified catalyst a product with only $40 \%$ ee could be obtained, ${ }^{[6]}$ and a subsequent resolution was required in order to upgrade the ee to enantiopurity.

This drawback led to the development of yet another route, where the key step is the addition of isobutyl lithium to the chiral sulfinimide 6 (Scheme 2). Hydrolysis of the resulting product gives $(R)-\mathbf{3}$ with excellent yield and enantiopurity. ${ }^{[7]}$ This methodology has also recently been applied for the preparation of active, hydroxylated metabolites of sibutramine. ${ }^{[8]}$ However, in both cases, the addition is a low-temperature reaction (optimum temperature $-78^{\circ} \mathrm{C}$ for 6 to 3 ), and the required auxiliary, which has to be prepared in three steps, is destroyed and thus lost during the workup.

${ }^{{ }^{*} \text { Correspondence: }}$ Dr. U. Berens ${ }^{\mathrm{a}}$, Dr. A. Hafner ${ }^{\mathrm{b}}$ aBASF SE

GCI/P-M 311

D-67056 Ludwigshafen am Rhein, Germany

Tel.: +49621604 8030

E-mail: ulrich.berens@basf.com

${ }^{\mathrm{b}} \mathrm{Ciba}$ Inc. (now part of BASF)

Performance Chemicals Research

Klybeckstrasse 141, CH-4002 Basel

Tel.: +41616365437

E-mail: andreas.hafner@ciba.com

'Solvias AG

Klybeckstrasse 191

$\mathrm{CH}-4002$ Basel

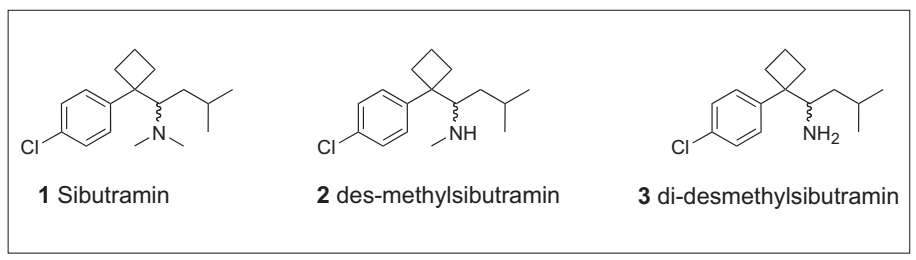

Fig 1.

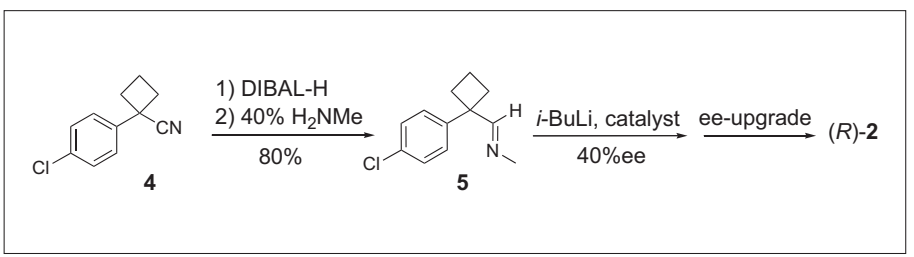

Scheme 1. 


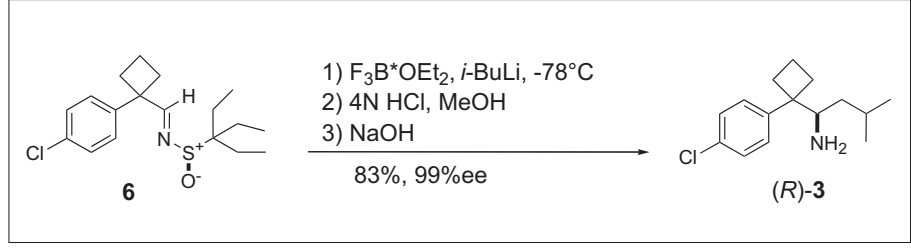

Scheme 2.

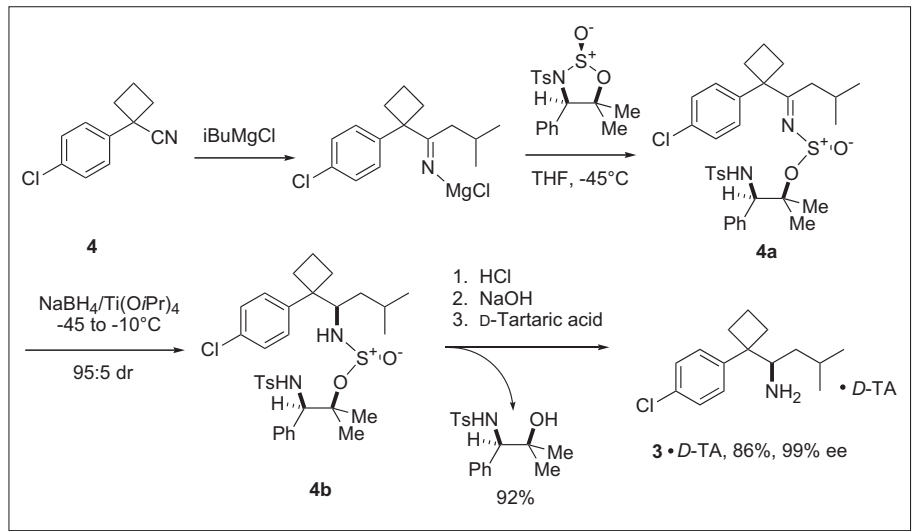

Scheme 3

Very recently, the issue of the recovery of the chiral auxiliary has been addressed (Scheme 3). ${ }^{[9]}$ The new route involves the reaction between the condensation product of nitrile 4 and $i$ - $\mathrm{BuMgCl}$, and an optically pure oxathiazolidine-2-oxide to deliver sulfinate imines $4 \mathbf{a}$. The highly diastereoselective reduction $(95: 1 \mathrm{de})$ of these imine derivatives to compounds 4b could be optimized to 95:5 de, albeit at low temperatures again $\left(-45^{\circ} \mathrm{C}\right)$ and with stoichiometric amounts of the wasteproducing reducing agent $\mathrm{NaBH}_{4}$ in combination with $\mathrm{Ti}(\mathrm{O} i \mathrm{Pr})_{4}$. Crystallisation of the D-tartrate salt of the obtained di-desmethylsibutramine $\mathbf{3}$ after hydrolysis and di-methylation finally led to optically pure sibutramine. On multigram scale, the chiral auxiliary could be recovered in $92 \%$ yield after hydrolysis of the reduction product.

Defining the stereochemistry of the stereogenic carbon of $\mathbf{3}$ via enantioselective hydrogenation of a suitable substrate with high $e e$ would circumvent the formation of the undesired enantiomer and thus its loss, respectively the need to utilize this material for example by a racemisation/resolution process. As mono- or di-methylation is easy to perform, we devised a new, catalytic asymmetric route to $\mathbf{3}$, as this provides also an efficient access to the full range of our target compounds $\mathbf{1}-\mathbf{3}$.

\section{Results and Discussion}

Compounds such as $\mathbf{8}$ appear to be suitable hydrogenation substrates, as it is well documented that enamides of this type can be hydrogenated very efficiently with cationic rhodium complexes of DuPHOStype ligands. ${ }^{[10 a]}$ Such enamides have been obtained by the reduction of oxime 7 with iron powder in the presence of acetic acid and acetic anhydride (Scheme 4).

In our case however, the reduction of oxime 7 according to the published protocol provided 8 only in a maximum $30 \%$ yield. An alternative approach to such enamides involves the reaction of Grignard reagents with nitriles. However, this approach usually requires chromatographic purification of the products and yields are low. ${ }^{[10 b, c]}$ It was thus surprising that the reaction of isobutyl magnesium chloride with nitrile $\mathbf{4}$ and in situ treatment of the reaction mixture with acetic anhydride gave enamide $\mathbf{8}$ in $62 \%$ yield. This is a dramatic yield improvement, as alone for the synthesis of $\mathbf{7}$ three additional steps are required: i) aqueous quench of the Grignard addition reaction, ii) hydrolysis of the imine with hydrochloric acid to the ketone, and iii) formation of the oxime 7 .

Quite surprisingly and in strong contrast to reported results, ${ }^{[10 a]}$ the catalytic hydrogenation of $\mathbf{8}$ with cationic rhodium catalysts such as [Rh-(COD)(MeDuPHOS) $] \mathrm{BF}_{4}$, [Rh-(COD)-(Me$\mathrm{BPE})] \mathrm{BF}_{4}$, or [Rh-(COD)-(Et-Ferrotane)] $\mathrm{BF}_{4}$ or even with the very active catalyst [Rh-(COD)-(Dipfc) $\mathrm{BF}_{4}{ }^{[11]}$ was extremely sluggish even under drastic conditions. As the unexpectedly low reactivity of $\mathbf{8}$ most probably originates from the severe steric shielding of the enamide $\mathrm{C}=\mathrm{C}$ double bond, a sterically less congested hydrogenation substrate was sought.
Thus, nitrile 4 was reacted with methallyl magnesium chloride, and the reaction mixture treated with acetic acid anhydride (Scheme 5). After de-acetylation of the intermediate diacetate 10a with sodium methoxide the novel dienamide $\mathbf{1 0}$ was after recrystallization obtained as the $Z$ stereoisomer in $67 \%$ yield, whilst the crude yield of $\mathbf{1 0}$ was almost quantitative.

\section{Catalysis}

Substrates which are closely related to 10 have been hydrogenated with cationic rhodium catalysts derived from DuPHOStype ligands to provide the $\gamma, \delta$-unsaturated amide with excellent chemo- and enantioselectivity. ${ }^{[12]}$ From the literature, the expected product from amide $\mathbf{1 0}$ should be 11a. Surprisingly, hydrogenation of enamide 10 with rhodium catalysts derived from the achiral ligands Dipfc and the biaryldiphosphine BiPHEP (Fig. 2) gave 8 quantitatively (Table 1). This means that not as reported the $\alpha, \beta$-but the $\gamma, \delta$-double bond is hydrogenated preferentially, which results in the formation of the inactive substrate 8. Employing the $(S, S)$-Et-DuPHOS ligand under quite harsh conditions furnished compound 11a in only $25 \%$ yield (ee not determined) together with $9 \%$ saturated amide $\mathbf{9}$, in $66 \%$ ee $(R)$.

As hydrogenation of enamides with ruthenium-based catalysts is well documented, ${ }^{[13]}$ we also tested $\left[\mathrm{RuCl}_{2}-(p \text {-cymene })\right]_{2}$ in combination with Biphep, and were delighted to obtain 9 cleanly in quantitative yield. 


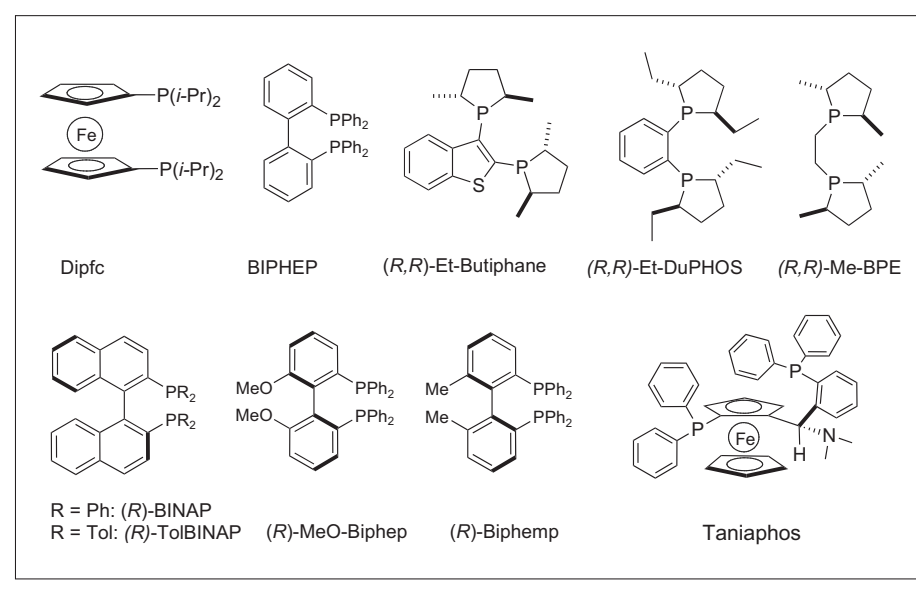

Fig. 2. Ligands used in catalytic hydrogenations

Table 1. Rh- and Ru-catalysed hydrogenation of enamide 10

\begin{tabular}{|c|c|c|c|c|c|c|c|c|}
\hline \multirow[b]{2}{*}{ Catalyst Precursor } & \multirow[b]{2}{*}{ Ligand } & \multirow[b]{2}{*}{$\mathrm{S} / \mathrm{C}$} & \multirow[b]{2}{*}{ Solvent } & \multirow[b]{2}{*}{$\begin{array}{c}\mathrm{pH}_{2} \\
\text { [bar] }\end{array}$} & \multirow[b]{2}{*}{$\begin{array}{c}\mathbf{T} \\
{\left[{ }^{\circ} \mathrm{C}\right]}\end{array}$} & \multicolumn{3}{|c|}{ Products } \\
\hline & & & & & & $\begin{array}{c}9 \\
\text { [APa \%] }\end{array}$ & $\begin{array}{c}11 \\
{\left[\mathrm{AP}^{\mathrm{a}} \%\right]}\end{array}$ & $\begin{array}{c}8 \\
\text { [APa \%] }\end{array}$ \\
\hline$[\mathrm{Rh}-(\mathrm{COD})-\mathrm{Dipfc}] \mathrm{BF}_{4}$ & - & 200 & $\mathrm{MeOH}$ & 5 & 25 & 0 & $<1 \%$ & 100 \\
\hline$[\mathrm{Rh}-(\mathrm{COD})-\mathrm{Dipfc}] \mathrm{BF}_{4}$ & - & 50 & $\mathrm{MeOH}$ & 10 & 60 & 0 & $<1 \%$ & 100 \\
\hline$[\mathrm{Rh}-(\mathrm{NBD})-\mathrm{Cl}]_{2}$ & BIPHEP & 100 & DCE & 20 & 50 & 0 & $<1 \%$ & 100 \\
\hline $\begin{array}{l}\text { [Rh-(COD)-(S,S)- } \\
\text { EtDuPHOS]BF }_{4}\end{array}$ & & 100 & $\mathrm{MeOH}$ & 20 & 50 & $9^{b}$ & $25^{c}$ & 66 \\
\hline$\left[\mathrm{RuCl}_{2} \text {-(p-cymene) }\right]_{2}$ & BIPHEP & 100 & $\mathrm{MeOH}$ & 50 & 50 & 100 & $<1 \%$ & 0 \\
\hline
\end{tabular}

Reaction conditions: 150-200 mg starting material; [10] = 0.15-0.2 M; reaction time 16-17 h; $\mathrm{AP}=\mathrm{HPLC}$ peaks; a Area percentage; bee not determined; ${ }^{\circ} 66 \%$ ee $(R)$.

Table 2. Catalyst screening for the hydrogenation of 10 with chiral ruthenium catalysts at $\mathrm{S} / \mathrm{C}=100$

\begin{tabular}{|c|c|c|c|c|c|c|c|}
\hline Entry & $\begin{array}{l}\text { Precursor / Ligand } \\
\text { or Precatalyst }\end{array}$ & $\begin{array}{l}\mathrm{pH}_{2} \\
\text { [bar] }\end{array}$ & $\begin{array}{c}\mathbf{T} \\
{\left[{ }^{\circ} \mathrm{C}\right]}\end{array}$ & $\begin{array}{l}\text { Conv. } \\
\text { of } \\
10 \\
\text { [AP \%] }\end{array}$ & $\begin{array}{c}8 \\
{[\text { AP \%] }}\end{array}$ & $\begin{array}{c}9 \\
\text { [AP \%] }\end{array}$ & $\begin{array}{l}\text { ee } 9 \\
{[\%]}\end{array}$ \\
\hline 1 & {$\left[\mathrm{RuCl}_{2}(p \text {-cymene })\right]_{2} /(R)$-BINAP } & 50 & 50 & 100 & 0 & 100 & 93.9 \\
\hline 2 & {$\left[\mathrm{RuCl}_{2}(p \text {-cymene })\right]_{2} /(R)$-BINAP } & 50 & 25 & 67 & 52 & 13 & 98.6 \\
\hline 3 & {$\left[\mathrm{RuCl}_{2}(p \text {-cymene })\right]_{2} /(R)$-BINAP } & 50 & 80 & 100 & 1 & 98 & 38.5 \\
\hline 4 & {$\left[\mathrm{RuCl}_{2}(\mathrm{p} \text {-cymene })\right]_{2} /(R)$-BINAP } & 10 & 50 & 100 & 23 & 76 & 5.1 \\
\hline 5 & {$\left[\mathrm{RuCl}_{2}(p \text {-cymene })\right]_{2} /(R)$-BINAP } & 90 & 50 & 100 & 25 & 75 & 2.5 \\
\hline 6 & $\mathrm{RuCl}_{3}{ }^{*} 3 \mathrm{H}_{2} \mathrm{O} /(R)-$ BINAP & 50 & 50 & 100 & 58 & 41 & .9 \\
\hline 7 & {$\left[\mathrm{RuCl}_{2}-(R)-\mathrm{BINAP}\right]_{2} \mathrm{NEt}_{3}$} & 50 & 50 & 100 & 15 & 84 & 92.9 \\
\hline 8 & {$[\mathrm{RuCl}-(R)-\mathrm{BINAP}$-(p-cymene)]Cl } & 50 & 50 & 100 & 10 & 89 & 91.0 \\
\hline 9 & {$\left[\operatorname{RuCl}_{2}(p \text {-cymene })\right]_{2} /(R)$-TolBINAP } & 50 & 50 & 100 & 0 & 100 & 93.7 \\
\hline 10 & {$\left[\mathrm{RuCl}_{2}(p \text {-cymene })\right]_{2} /(R)$-Biphemp } & 50 & 50 & 100 & 0 & 100 & 95.4 \\
\hline 11 & $\begin{array}{l}{\left[\mathrm{RuCl}_{2}(p \text {-cymene })\right]_{2} /} \\
(R) \text {-MeOBIPHEP }\end{array}$ & 50 & 50 & 100 & 0 & 100 & 98.3 \\
\hline 12 & $\begin{array}{l}{\left[R u C l_{2}(p \text {-cymene })\right]_{2} /} \\
(S)-(R) \text {-Taniaphos }\end{array}$ & 50 & 50 & 100 & 89 & 11 & 89.1 \\
\hline 13 & $\begin{array}{l}{\left[\mathrm{RuCl}_{2}(p \text {-cymene })\right]_{2} /} \\
R, R) \text {-Me-Butiphane }\end{array}$ & 50 & 50 & 95 & 84 & 16 & 20 \\
\hline $14^{\mathrm{a}}$ & $\begin{array}{l}{\left[\mathrm{RuCl}_{2}(\mathrm{p} \text {-cymene })\right]_{2} /} \\
(R) \text {-MeOBIPHEP }\end{array}$ & 50 & 50 & - & 40 & 60 & 85 \\
\hline
\end{tabular}

Reaction conditions: $150-200 \mathrm{mg}$ starting material; $10=0.15-0.2 \mathrm{M}$ in EtOH; reaction time 16 $\mathrm{h},(R)-9$ preferentially formed in each case; ${ }^{a} E$ namide 8 as starting material.
This prompted us to evaluate the performance of chiral ruthenium catalysts in the asymmetric hydrogenation of $\mathbf{1 0}$, which were derived from axially chiral enantiopure ligands such as BINAP or BIPHEMP and the like (Table 2).

It was a pleasing finding that both satisfactory conversions and high $e e$ could be accomplished with these ligands. At $50{ }^{\circ} \mathrm{C}$ and 50 bar hydrogen pressure, full conversion to the desired amide 9 in $93.9 \%$ ee $(R)$ was observed using the $(R)$-BINAP ligand. These reaction conditions seem to represent a good compromise for high performance of the catalyst, since lowering (entry 2 ) or rising (entry 3 ) the temperature had a detrimental effect on catalytic activity and selectivity, respectively. An analogous effect of hydrogen pressure on the course of the reaction was observed (entries 4-5). Under otherwise similar conditions, other ruthenium/ BINAP catalysts were found to be both less active and selective (entries 5-7).

From the testing of several other chiral diphosphines (entries 9-13), the MeOBiPheP ligand provided best performance with $98.3 \%$ ee and full conversion. Interestingly but unexpectedly, enamide $\mathbf{8}$ is not fully reduced under the same reaction conditions, (entry 14).

Hydrogenation of dienamide $\mathbf{1 0}$ appears to produce 11a as the primary product, as enamide $\mathbf{8}$ cannot be hydrogenated efficiently with the employed ruthenium catalysts. Quite interestingly, intermediate 11a was rarely detected in concentrations exceeding $\mathrm{ca}$. $2 \%$, which means that the remaining double bond is hydrogenated rather rapidly with a homogeneous catalyst to give 9. This indicates that presumably an amide directed homogeneous hydrogenation is in operation. It would be interesting to study whether this second hydrogenation is also enantioselective by employing a prochiral analogue of 11a, but no work towards this end was undertaken.

With these first results at hand, we further optimized the reaction, employing BINAP (the cheapest axially chiral diphosphine) and MeOBiPheP (most effective for our transformation at $\mathrm{S} / \mathrm{C}=100$ ) as ligands and at higher substrate/catalyst ratios, typically $\mathrm{S} / \mathrm{C}=500$ (Table 3 ).

Although the hydrogenation of $\mathbf{1 0}$ with BINAP provides the desired amide 9 in high ee, at high substrate/catalyst ratios the conversion was not satisfactory. Whereas the addition of trifluoroethanol or mixtures of ethanol with dichloromethane or tetrahydrofurane gave no improvement (entries 2-4), it was possible to achieve full conversion at $\mathrm{S} / \mathrm{C}=1000$, when a small quantity of hydrochloric acid was added to the reaction mixture (entry 5). This was however at the cost of enantioselectivity, which dropped to $84.7 \%$ ee. 
Table 3. Asymmetric hydrogenation of $\mathbf{1 0}$ with chiral ruthenium catalysts at $S / C \geq 500$

\begin{tabular}{|c|c|c|c|c|c|c|c|c|}
\hline Entry & Ligand & Solvent & $\begin{array}{c}\mathrm{pH}_{2} \\
\text { [bar] }\end{array}$ & $\begin{array}{c}\mathbf{T} \\
{\left[{ }^{\circ} \mathrm{C}\right]}\end{array}$ & $\begin{array}{c}\text { Conv. } \\
\text { of } 10 \\
\text { [AP \%] }\end{array}$ & $\begin{array}{c}8 \\
\text { [AP \%] }\end{array}$ & $\begin{array}{c}9 \\
{[\mathrm{AP} \%]}\end{array}$ & $\begin{array}{l}\text { ee } 9 \\
\text { [\%] }\end{array}$ \\
\hline 1 & $(R)$-BINAP & $\mathrm{EtOH}$ & 50 & 50 & 95 & 65 & 30 & 98.0 \\
\hline 2 & $(R)$-BINAP & $\mathrm{EtOH} / \mathrm{DCM}(4: 1)$ & 50 & 50 & 100 & 28 & 72 & 91.9 \\
\hline 3 & $(R)$-BINAP & EtOH/THF (1:4) & 50 & 50 & 100 & 92 & 8 & 27 \\
\hline 4 & $(R)$-BINAP & TFE & 50 & 50 & 100 & 94 & 6 & 28 \\
\hline $5^{\mathrm{a}}$ & (R)-BINAP & $\mathrm{EtOH}$ & 50 & 50 & 100 & 0 & 100 & 84.7 \\
\hline $6^{b}$ & (R)-MeOBIPHEP & $\mathrm{EtOH}$ & 50 & 50 & 100 & 0 & 100 & 98.5 \\
\hline 7 & (R)-MeOBIPHEP & $\mathrm{EtOH}$ & 50 & 80 & 100 & 0 & 100 & 96.4 \\
\hline 8 & (R)-MeOBIPHEP & $i-\mathrm{PrOH}$ & 50 & 70 & 100 & 58 & 42 & 92.1 \\
\hline $9^{c}$ & (R)-MeOBIPHEP & $\mathrm{EtOH}$ & 50 & 50 & 62 & 25 & 17 & 97 \\
\hline $10^{d}$ & (R)-MeOBIPHEP & $\mathrm{EtOH}$ & 50 & 50 & 12 & 6 & 5 & n.d. \\
\hline $11^{\mathrm{e}}$ & १)-МeOBIPHEP & EtOH & 50 & 100 & 100 & 0 & 100 & 2 \\
\hline
\end{tabular}

Reaction conditions: $1-2 \mathrm{~g}$ starting material, metal precursor: $\left[\mathrm{RuCl}_{2}(p \text {-cymene) }]_{2}\right.$ unless otherwise noted, [10] $=0.15-0.2 \mathrm{M}$ in solvent; reaction time 16-26 $\mathrm{h},(R)-9$ preferentially formed in each case; a 0.4 eq. $\mathrm{HCl}_{\text {aq }} 1 \mathrm{M}$ relative to dienamide 10 was added, $\mathrm{S} / \mathrm{C}=1000$; b20.0 g scale; $\left.{ }^{c}[\mathrm{Ru}-(\mathrm{R})-\mathrm{MeOBiphep-(TFA})_{2}\right]$ as catalyst; ${ }^{\mathrm{d}}\left[\mathrm{Ru}-(\mathrm{R})-\mathrm{MeOBiphep}-(\mathrm{OAc})_{2}\right]$ as catalyst; ${ }^{\mathrm{e}} \mathrm{S} / \mathrm{C}=1500$.

In contrast, when the MeOBiPheP ligand was employed, the reaction went smoothly to completion and provided $(R)$ 9 quantitatively in excellent $98.5 \%$ ee on $20 \mathrm{~g}$ scale (entry 6). Modifying the pressure, temperature and nature of solvent or employing isolated ruthenium catalysts ${ }^{[14]}$ led to erosion of activity and/or selectivity. At $\mathrm{S} / \mathrm{C}=1500$, it was necessary to rise the temperature to $100{ }^{\circ} \mathrm{C}$ in order to achieve full conversion (entry 11). In this case the isolated product had $95.2 \%$ ee .

Interestingly, the crystalline solid amide 9 of high enantiomeric purity $(>92 \%)$ was found to lend itself to an $e e$ upgrade by crystallisation. When $(R)-9$ with an enantiomeric purity of $96.6 \%$ was recrystallized from di-isopropyl ether, the recovered amide (72\%) had an $e e$ of $99.7 \%$. This behavior of 9 is a very useful feature of the present synthesis, as the possibility to upgrade the ee allows a freer choice between a variety of hydrogenation catalysts respectively the corresponding ligands.

The de-acetylation of $\mathbf{9}$ to give $\mathbf{3}$ was successfully accomplished with $\mathrm{HCl}$ at elevated temperature. Surprisingly, even under the harsh conditions required for the cleavage, the enantiomeric excess of the starting material is retained in the product. When a material with $95.1 \%$ ee $(R)$ was hydrolyzed and re-acetylated under standard conditions ( $\mathrm{Ac}_{2} \mathrm{O}$, DMAP cat., $\mathrm{CH}_{2} \mathrm{Cl}_{2}$, r. t., $3 \mathrm{hrs}$, see Experimental section), $(R)-\mathbf{9}$ was obtained back in $67 \%$ ee and $95.7 \%$ ee (no direct assay for $\mathbf{3}$ was available).
Finally, $(R)$-di-des-methylsibutramine 3 could be mono-methylated ${ }^{[15]}$ or dimethylated[16] according to literature procedures, thus completing the synthesis of both $(R)$-des-methylsibutramine and $(R)$ sibutramine.

\section{Conclusion}

The first catalytic asymmetric synthesis of $(R)$-di-des-methylsibutramine $\mathbf{3}$, a precursor to the anti-obesity drug sibutramine $\mathbf{1}$, has been achieved in $49 \%$ overall yield $(3 \cdot \mathrm{HCl}$ salt) from nitrile 4 . The enantioselective hydrogenation of intermediate dienamide 10 proved only feasible with ruthenium-based catalysts. Optimization studies have shown that the atropoisomeric biaryldiphosphine MeOBiPheP is most effective for this transformation, bringing excellent conversion and enantioselectivity (up to $98.5 \% e e$ ). The cheap BINAP ligand proved also interesting in particular in view of large-scale applications and for overall process cost reasons (although further optimization would be needed). We anticipate that this synthetic route should be amenable to the large-scale production of optically pure sibutramine $\mathbf{1}$ and derivatives thereof.

\section{Experimental}

NMR spectra were recorded on a Varian $400 \mathrm{MHz}$ spectrometer. Chemical shifts are reported in parts per million (ppm) relative to external standard TMS $\left({ }^{1} \mathrm{H}\right.$, ${ }^{13} \mathrm{C}$ ). Chemicals were ordered from Strem (for metal complexes and ligands), Fluka or Aldrich and used as received. Solvents were ordered from Fluka or Aldrich and freshly distilled before use under argon atmosphere: $\mathrm{EtOH}(\mathrm{Mg}), \mathrm{CH}_{2} \mathrm{Cl}_{2}$ and toluene $\left(\mathrm{CaH}_{2}\right)$, THF and diethethylether $(\mathrm{Na} /$ benzophenone). Trifluoroethanol was used as received from Aldrich. The ruthenium catalysts were prepared according to. ${ }^{[14]}$

\section{Synthesis of 8 via Nitrile Alkylation}

A dry three-necked $500 \mathrm{ml}$ flask with nitrogen inlet was charged with 1-(4-chlorophenyl)-cyclobutanecarbonitrile $(4,20.1 \mathrm{~g}$, $105 \mathrm{mmol})$ and dry toluene $(300 \mathrm{ml})$. The mixture was cooled to $5{ }^{\circ} \mathrm{C}$, and then isobutyl magnesium bromide ( $79 \mathrm{ml}$ of a $2 \mathrm{M}$ solution in diethyl ether, $158 \mathrm{mmol}$ ) was added within $15 \mathrm{~min}$. The reaction mixture was heated to $105^{\circ} \mathrm{C}$, and the diethyl ether was continuously removed by distillation. The mixture was kept at reflux $\left(105^{\circ} \mathrm{C}\right)$, and after $1 \mathrm{~h}$ the starting material was consumed completely (TLC). The reaction mixture was then cooled to $5{ }^{\circ} \mathrm{C}$, and after the addition of acetic anhydride $(32.1 \mathrm{~g}, 315$ mmol) the yellow suspension was stirred at room temperature for another $3 \mathrm{~h}$. The reaction was quenched with methanol (30 $\mathrm{ml}$ ), and then neutralized with a saturated sodium hydrogen carbonate solution (200 $\mathrm{ml}$ ). After the addition of diethyl ether (300 $\mathrm{ml})$ two layers formed. The organic layer was washed twice with water, and dried over sodium sulfate. Evaporation of the solvent in vacuo gave a yellow-orange solid (35 g), which was recrystallized from hexane to give $\mathbf{8}$ as pale yellow crystals (19 g, $62 \%)$. From ${ }^{1} \mathrm{H}-\mathrm{NOE}$ experiments the product is the $(Z)$-stereoisomer.

${ }^{1} \mathrm{H}$ NMR (DMSO-D6, $300 \mathrm{MHz}$ ): $\delta$ $0.88\left(\mathrm{~d}, 6 \mathrm{H},{ }^{3} \mathrm{~J}=6.8 \mathrm{~Hz}, 2 \mathrm{CH}_{3}\right) ; 1.60-1.90$ m (2 H, $\left.\mathrm{CH}_{2} \mathrm{CH}_{2} \mathrm{CH}_{2}\right) ; 1.78\left(\mathrm{~s}, 3 \mathrm{H}, \mathrm{CH}_{3}\right)$; 2.10-2.32( $\left.\mathrm{m}, 2 \mathrm{H}, \mathrm{CH}_{2} \mathrm{CH}_{2} \mathrm{CH}_{2}\right) ; 2.28(\mathrm{~m}$, $\left.1 \mathrm{H}, \mathrm{CH}\left(\mathrm{CH}_{3}\right)_{2}\right) ; 2.40-2.50\left(2 \mathrm{H}, \mathrm{CH}_{2} \mathrm{CH}_{2}-\right.$ $\left.\mathrm{CH}_{2}\right) ; 5.15(\mathrm{~d}, 1 \mathrm{H}, \mathrm{J}=9.6 \mathrm{~Hz}, \mathrm{C}=\mathrm{CH})$; $7.21,7.28(2 * 2 \mathrm{H}$, Ar-H); 8.09 (br s, 1 $\mathrm{H}, \mathrm{NH})$.

${ }^{13} \mathrm{C}$ NMR (DMSO-D6, $\left.75 \mathrm{MHz}\right): \delta$ $16.58\left(\mathrm{CH}_{2}\right) ; 23.16\left(2 \mathrm{CH}_{3}\right) ; 23.59\left(\mathrm{CH}_{3}\right)$; $27.39(\mathrm{CH}) ; 32.76\left(2 \mathrm{CH}_{2}\right) ; 52.13(\mathrm{C})$; 128.34, 128.92 (4 $\mathrm{Ar} \mathrm{CH}) ; 130.83(\mathrm{Ar}$ $\mathrm{C}-\mathrm{Cl}) ; 131.31(\mathrm{C}=\mathrm{CH}) ; 136.83(C=\mathrm{CH})$; 146.57 (Ar C); $168.46(\mathrm{C}=\mathrm{O})$.

\section{Synthesis of (Z)-N-\{1-[1-(4-Chloro- phenyl)-cyclobutyl]-3-methyl-buta- 1,3-dienyl\}-acetamide 10}

A dry $500 \mathrm{ml}$ three-necked flask with nitrogen inlet was charged with 1-(4-chloro-phenyl)-cyclobutanecarbonitrile (4, $20.1 \mathrm{~g}, 105 \mathrm{mmol})$ and dry THF $(300 \mathrm{ml})$. The mixture was cooled to $5^{\circ} \mathrm{C}$, and methallyl magnesium chloride $(105 \mathrm{ml}$ of a 
freshly prepared solution $1.5 \mathrm{M}$ in THF, $158 \mathrm{mmol}, 1.5$ eq.) was added within 30 min. The reaction mixture was stirred for another $30 \mathrm{~min}$ at $5{ }^{\circ} \mathrm{C}$, and then slowly warmed to room temperature, before acetic anhydride $(315 \mathrm{ml}$ of a $1 \mathrm{M}$ solution in THF, $315 \mathrm{mmol}, 3$ eq.) was added. The orange reaction mixture was stirred at 60 ${ }^{\circ} \mathrm{C}$ until the acetylation was complete (2-4 $\mathrm{h}$, monitored by TLC). This gave a mixture, which contained both $\mathbf{1 0}$ and the Ndi-acetylated product ( $c a$. 1:2 ratio). The excess of acetic anhydride was quenched with $20 \mathrm{ml}$ methanol, and after the addition of sodium methylate ( $160 \mathrm{~g}$ of a $15 \%$ solution in methanol, $445 \mathrm{mmol}$ ), and further stirring for $15 \mathrm{~min}$ the by-product 11a had been de-acetylated to give $\mathbf{1 0}$. The reaction mixture was then diluted with ethylacetate $(250 \mathrm{ml})$, and then washed with saturated ammonium chloride $(500 \mathrm{ml})$, brine $(500$ $\mathrm{ml})$, and water $(500 \mathrm{ml})$. The organic layer was dried (sodium sulfate), and removal of the solvent in vacuo gave $\mathbf{1 0}(30 \mathrm{~g})$ as beige crystals. Recrystallization from di-isopropyl ether furnished pure 10 (20 g, $67 \%)$ as pale beige crystals. From ${ }^{1} \mathrm{H}-\mathrm{NOE}$ experiments the major stereoisomer is the (Z)-stereoisomer, $\mathrm{mp}=120{ }^{\circ} \mathrm{C}$.

${ }^{1} \mathrm{H}$ NMR (DMSO-D6, $300 \mathrm{MHz}$ ): $\delta$ 1.63-1.74 (m, $2 \mathrm{H}, \mathrm{CH}_{2}$ ); 1.74 (s (br), 3 $\left.\mathrm{H}, \mathrm{CH}_{3}\right) ; 1.78$, (s, $\left.3 \mathrm{H}, \mathrm{CH}_{3} \mathrm{C}=\mathrm{O}\right) ; 2.28$, $2.49\left(2 \mathrm{~m}, 2 \mathrm{H}\right.$ each, $\left.2 \mathrm{CH}_{2}\right) ; 4.81(\mathrm{~s}, 1 \mathrm{H}$, $\left.Z-\mathrm{C}=\mathrm{CH}_{2}\right) ; 4.91\left(\mathrm{~s}, 1 \mathrm{H}, E-\mathrm{C}=\mathrm{CH}_{2}\right) ; 5.95$ (s, 1 H, C=CH); 7.26, 7.30 (m, $2 \mathrm{H}$ each, $\mathrm{H}$-aryl); 8.34 (s (br), NH).

${ }^{13} \mathrm{C}$ NMR (DMSO-D6, $75 \mathrm{MHz}$ ): $\delta 16.57 \quad\left(\mathrm{CH}_{2}\right) ; 21.39 \quad\left(\mathrm{CH}_{3}\right) ; 23.53$ $\left(\mathrm{CH}_{3} \mathrm{C}=\mathrm{O}\right) ; 33.11\left(2 \mathrm{CH}_{2}\right) ; 53.33(\mathrm{C})$, $117.93\left(\mathrm{C}=\mathrm{CH}_{2}\right) ; 125.77(\mathrm{C}=\mathrm{CH}) ; 128.43$, 129.11(4 Ar CH); 130.99 (Ar C-Cl) 139.80 $(\mathrm{NC}=\mathrm{C}) ; 141.42\left(C=\mathrm{CH}_{2}\right) ; 146.35(\mathrm{Ar} \mathrm{C})$; $169.22(\mathrm{C}=\mathrm{O})$.

\section{Hydrogenation Screening of 10 with Achiral Rhodium and Ruthe- nium Catalysts}

Typical procedure: To a $10 \mathrm{ml}$ Schlenk flask with a magnetic stirring bar was charged the respective catalyst. The Schlenk flask was evacuated and flushed with argon three times. Then the degassed solvent $(3 \mathrm{ml})$ was added, and the catalyst dissolved. The substrate $\mathbf{1 0}$ was transferred into a $25 \mathrm{ml}$ Schlenk flask, which was purged by three cycles vacuum/argon flushing, and then dissolved in the solvent $(3 \mathrm{ml})$. The solution of both the catalyst and the substrate were transferred sequentially into a $50 \mathrm{ml}$ thermostated stainless steel autoclave, which was equipped with a magnetic stirring bar under an argon atmosphere. The autoclave was submitted to hydrogen pressure (10 bar) and the pressure released. After three cycles, the pressure and temperature were set to the desired level, and $20 \mathrm{~min}$ later magnetic stir- ring was started. After $17 \mathrm{~h}$ the autoclave was cooled to ambient temperature and the pressure released. The resulting pale yellow solution was evaporated under reduced pressure (rotavapor, max bath $\mathrm{T} /{ }^{\circ} \mathrm{C}=40$ ) to give the product mixture which was analyzed using the following assay.

\section{Analytical Assay for the Hydro- genation Products and Starting Materials}

The following HPLC-method was used for the determination of the ee of the products. For the assignment of the absolute stereochemistry of $\mathbf{3}$ a small quantity of this material was prepared as described in the literature. ${ }^{[7]}$

Column: Chiracel OD-H, diam. $=0.46$ $\mathrm{cm}$, length: $25 \mathrm{~cm}$, mobile phase hexane/ EtOH 98:2, flow: $0.7 \mathrm{ml} / \mathrm{min}$, temperature: $25^{\circ} \mathrm{C}$, detection $230 \mathrm{~nm}$, injection volume: $1.0 \mu \mathrm{l}$, sample preparation: $c a .5 \mathrm{mg}$ in 1 $\mathrm{ml}$ hexane/ethanol (4:1). Retention times: di-enamide 10: $23.6 \mathrm{~min}$, mono-enamide 8: $17.2 \mathrm{~min}$, enantiomers of amide 11: 14.5 and $15.5 \mathrm{~min}$, amide $(S)$-9: $12.9 \mathrm{~min}$, amide $(R)-9$ : 13.9 min.

\section{Enantioselective Hydrogenation of 10 at $S / C=1500$}

A $10 \mathrm{ml}$ Schlenk flask equipped with a magnetic stirring bar was charged with $\left[\mathrm{Ru}-\mathrm{Cl}_{2}\right.$-(p-cymene $\left.)\right]_{2}(1.40 \mathrm{mg}, 2.3 \mu \mathrm{mol})$ and $(R)$-MeOBiPheP $(2.80 \mathrm{mg}, 4.8 \mu \mathrm{mol})$, evacuated under high vacuum/argon flushing (this operation was repeated three times) and $\mathrm{EtOH}(3 \mathrm{ml})$ added with stirring. Dienamide 10 (2.00 g, $6.90 \mathrm{mmol})$ was taken into a $25 \mathrm{ml}$ Schlenk flask, set under argon and dissolved in ethanol (13 $\mathrm{ml}$ ). The catalyst and starting material solutions were transferred sequentially to a 50 $\mathrm{ml}$ thermostated stainless steel autoclave equipped with a magnetic stirring bar, under argon atmosphere. The autoclave was submitted to hydrogen pressure (10 bar) and the pressure released. After three cycles, the pressure was set to 50 bar and the temperature to $100{ }^{\circ} \mathrm{C} ; 20$ min later, magnetic stirring was started. After $17 \mathrm{~h}$, the pressure was released and the resulting pale yellow solution evaporated under reduced pressure (rotavapor, max bath $\mathrm{T} /{ }^{\circ} \mathrm{C}$ $=40$ ) to give amide 9 in quantitative yield and $95.2 \%$ ee $(R)$.

${ }^{1} \mathrm{H}-\mathrm{NMR}\left(\mathrm{CDCl}_{3}, 400 \mathrm{MHz}\right): \delta 0.59-$ $0.71,1.16-1.26\left(2 \mathrm{~m}, 1 \mathrm{H}\right.$ each, $\mathrm{CH}_{2}$ $\left.\mathrm{CHMe}_{2}\right) ; 0.82\left(\mathrm{~d}, 3 \mathrm{H}, \mathrm{J}=6.6 \mathrm{~Hz}, \mathrm{CH}_{3}\right)$; $0.95\left(\mathrm{~d}, 3 \mathrm{H}, \mathrm{J}=6.6 \mathrm{~Hz}, \mathrm{CH}_{3}\right) ; 1.39-1.52$ $\left(\mathrm{m}, 1 \mathrm{H}, \mathrm{CHMe}_{2}\right) ; 1.75-1.88(\mathrm{~m}, 1 \mathrm{H})$, 2.05-2.42(m, 5 H) $\left(\mathrm{CH}_{2} \mathrm{CH}_{2} \mathrm{CH}_{2}\right) ; 1.99$ (s, $\left.3 \mathrm{H}, \mathrm{COCH}_{3}\right) ; 4.52$ (m, $\left.1 \mathrm{H}, \mathrm{CHNAc}\right)$; 4.76 (br d, $1 \mathrm{H}, \mathrm{NH})$; 7.04, $7.29(2 \mathrm{~m}, 2 \mathrm{H}$ each, aryl $\mathrm{H})$.

${ }^{13} \mathrm{C}-\mathrm{NMR}\left(\mathrm{CDCl}_{3}, 100 \mathrm{MHz}\right) \delta 15.93$ $\left(\mathrm{CH}_{2} \mathrm{CH}_{2} \mathrm{CH}_{2}\right) ; 22.12\left(\mathrm{CH}_{3}\right) ; 23.96\left(\mathrm{CH}_{3}\right.$ $\mathrm{CO}) ; 24.29\left(\mathrm{CH}_{3}\right) ; 25.29\left(\mathrm{CHMe}_{2}\right) ; 31.89$,
$32.18\left(\mathrm{CH}_{2} \mathrm{CH}_{2} \mathrm{CH}_{2}\right) ; 40.22\left(\mathrm{CH}_{2}\right) ; 50.46$ (q C);53.17 (CNHAc); 128.13, 128.64 (Aryl CH); 132.01 (q, CCl); 144.39 (q, 4-ClPhC); $169.91\left(\mathrm{COCH}_{3}\right)$.

\section{Hydrogenation of 10 with the $R u-$ thenium/(R)-MeOBiPheP Catalyst on Large-scale at $S / C=500$.}

A $50 \mathrm{ml} \mathrm{Schlenk} \mathrm{flask} \mathrm{equipped} \mathrm{with}$ a magnetic stirring bar was charged with $\left[\mathrm{Ru}-\mathrm{CI}_{2} \text {-(p-cymene) }\right]_{2}(42.3 \mathrm{mg}, 69.0 \mathrm{mmol})$ and $(R)$-MeOBiPheP (80.4 mg, $138 \mathrm{mmol}$ ), evacuated under high vacuum/argon flushing (this operation was repeated three times) and then charged under stirring with dry, degassed EtOH (20 ml). Dienamide 10 (20.0 g, $69.0 \mathrm{mmol}$ ) was taken into a $300 \mathrm{ml}$ autoclave and set under argon. The catalyst solution was transferred via canula under argon atmosphere to the autoclave. Then $130 \mathrm{ml}$ of dry, degassed EtOH was transferred to the autoclave and the resulting mixture submitted to hydrogen pressure (10 bar) and the pressure released. After three cycles, the pressure was set to 50 bar and the temperature to $50{ }^{\circ} \mathrm{C}$; 30 min later, magnetic stirring was started. After $26 \mathrm{~h}$, an ${ }^{1} \mathrm{H}-\mathrm{NMR}$ of a reaction aliquot showed complete conversion to the desired product. The pressure was released, the autoclave set under argon and the pale yellow solution evaporated under reduced pressure (rotavapor, max bath $\mathrm{T} /{ }^{\circ} \mathrm{C}$ $=40$ ) to give amide 9 in quantitative yield $(19.9 \mathrm{~g})$ and $98.5 \% \mathrm{ee}(R) .[\alpha]_{\mathrm{D}}^{25}=+3.16$ (c $=10.065$ in $\mathrm{CHCl}_{3}$ ).

\section{Hydrolysis of Amide 9 to Di-des- methylsibutramin 3}

A $86 \mathrm{ml}$ tantalum autoclave equipped with a Teflon stirring bar was charged with 9 (1.0 g, $3.4 \mathrm{mmol}, 95.1 \%$ ee) and hydrochloric acid (50 $\mathrm{ml}, 37 \%$ in water, $185 \mathrm{mmol})$. The autoclave was closed and heating at $180^{\circ} \mathrm{C}$ was started. After 90 min the internal temperature had reached $180{ }^{\circ} \mathrm{C}$ at a pressure of 44 bar. After 9 h, the heating was stopped, and the reaction mixture cooled down to room temperature within $11 \mathrm{~h}$ (at that point the internal pressure was 3 bar). The pressure was released, the autoclave opened and the beige reaction mixture taken out (a small amount of a black thick oil had also formed on the upper wall). The autoclave was rinsed with distilled water $(3 \times 10 \mathrm{ml})$ and evaporation of the reaction mixture to dryness (rotavapor and high vacuum at $60{ }^{\circ} \mathrm{C}, 1 \mathrm{~h}$ ) gave $725 \mathrm{mg}$ of 3 (HCI salt) as a beige solid (73\%).

${ }^{1} \mathrm{H}$ NMR (DMSO-D6, $\left.300 \mathrm{MHz}\right): \delta 0.8$ (d, $\left.3 \mathrm{H}, \mathrm{CH}_{3}\right) ; 0.85$ (d, $\left.3 \mathrm{H}, \mathrm{CH}_{3}\right) ; 0.9,1.15$ (2M, $2 \mathrm{H}$ each, $\left.\mathrm{CH}_{2} \mathrm{CH}_{2} \mathrm{CH}_{2}\right) ; 1.6-1.65$ (m, $\left.2 \mathrm{H}, \mathrm{CHCH}_{2}\right) ; 1.9\left(\mathrm{~m}, 1 \mathrm{H}, \mathrm{CHCH}_{2}\right) ; 2.3$, $2.5\left(2 \mathrm{M}, 2 \mathrm{H}\right.$ each, $\left.\mathrm{CH}_{2} \mathrm{CH}_{2} \mathrm{CH}_{2}\right) ; 3.45$ (m, $1 \mathrm{H}, \mathrm{CHN}) ; 7.35,7.45(\mathrm{~m}, 2 \mathrm{H}$ each, $\mathrm{H}-$ aryl); 7.95 (s (br), $\mathrm{H}_{3} \mathrm{~N}^{+}$).

${ }^{13} \mathrm{C}$ NMR (DMSO-D6, $\left.75 \mathrm{MHz}\right) \delta 15.2$ $\left(\mathrm{CH}_{2}\right) ; 21.4\left(\mathrm{CH}_{3}\right) ; 23.5\left(\mathrm{CH}_{3}\right) ; 24.0(\mathrm{CH})$; 32.07 and $32.14\left(2 \mathrm{CH}_{2}\right) ; 37.7\left(\mathrm{CH}_{2}\right) ; 48.7$ 
Table 4. Enhancement of the enantiomeric purity of acetamide 9 by recrystallisation

\begin{tabular}{|cccccc|} 
Amide $\mathbf{9}[\mathrm{g}]$ & ee [\%] & $\begin{array}{c}\text { di-isoproyl- } \\
\text { ether }[\mathrm{ml}]\end{array}$ & $\begin{array}{c}\text { recryst. } 9 \\
{[\mathrm{~g}] /[\%] /}\end{array}$ & $\begin{array}{c}\text { ee recryst. } \\
{[\%]}\end{array}$ & $\begin{array}{c}\text { ee motherl. } \\
{[\%]}\end{array}$ \\
\hline 1.5 & 92.7 & 80 & $1.3 / 86.6$ & 92.2 & nd \\
\hline 2.5 & 96.6 & 130 & $1.8 / 72.0$ & 99.7 & 89.0 \\
\hline
\end{tabular}

(C), $55.9(\mathrm{C}-\mathrm{N}), 128.3$ and 130.0 (4 Ar $\mathrm{CH}) ; 131.6$ (Ar C-Cl); 142.3 (Ar C).

\section{Analysis of the ee of 3.HCl:}

An aliquot from the above de-acylation reaction mixture $(630 \mathrm{mg}$ of crude $3 \cdot \mathrm{HCl})$ was added to an aqueous solution of sodium hydroxide $(10 \mathrm{ml}, 1 \mathrm{M}$ in water, $10 \mathrm{mmol})$ and the mixture was extracted with dichloromethane $(3 \times 10 \mathrm{ml})$. The organic phase was dried (sodium sulfate), and directly taken into a $100 \mathrm{ml}$ flask with a stirring bar. Acetic acid anhydride $(0.40 \mathrm{ml}, 4.2$ mmol) was added dropwise with stirring at room temperature, followed by DMAP (51 mg, $0.42 \mathrm{mmol})$. After $3 \mathrm{~h}$, the reaction mixture was evaporated to dryness. The ee of this material was $95.7 \%$, which is within experimental error identical to the ee of the starting material 9 (95.1\% ee).

The crude brown solid was then purified by chromatography on silica gel (eluent: dichloromethane/methanol 95:5) to give $580 \mathrm{mg}$ of acetamide 9 as a beige solid. The yield for the sequence hydrolysis/ re-acetylation was $67 \%$, corrected for the aliquot which was used for the re-acetylation (Table 4).

Received: December 18, 2009

[1] A. Wirth, J. Krause, J. Am. Med. Assoc. 2001, 286,1331

[2] T. Jerussi, C. H. Senanayake, Q. K. Fang, PCT Application WO 00/10551.
[3] a) J. W. Young, PCT Application WO 94/00047; b) J. W. Young, PCT Application WO 94/00114.

[4] a) Q. K. Fang, C. H. Senanayake, Z. Han, C. Morency, P. Grover, R. E. Malone, H. Bulter, S. A. Wald, S. T. Cameron, Tetrahedron: Asymm. 1999, 10, 4477; b) Z. Han, D. Krishnamurthy, K. Q. Fang, S. A. Wald, C. H. Senanayake, Tetrahedron: Asymmetry 2003, 14, 3553.

[5] Z. Han, D. Krishnamurthy, D. Pflum, Q. K Fang, H. Butler, S. T. Cameron, S. A. Wald, C. H. Senanayake, Tetrahedron: Asymm. 2002, 13 , 107.

[6] D. Krishnamurthy, Z. Han, S. A. Wald, C. H. Senanayake, Tetrahedron Lett. 2002, 43, 2331.

[7] Z. Han, D. Krishnamurthy, D. Pflum, P. Grover, S. A. Wald, C. H. Senanayake, Org. Lett. 2002, $4,4025$.

[8] B. Z. Lu, C. Senananyake, N. Li, Z. Han, R. P. Bakale, S. A. Wald, Org. Lett. 2005, 7, 2599.

[9] Z. Han, D. Krishnamurthy, C. H. Senananyake, Org. Proc. Res. Dev. 2006, 10, 327.

[10] a) M. J. Burk, G. Casy, N. B. Johnson, J. Org. Chem. 1998, 63, 6084; b) Y. Heng-Suen, A. Horeau, H. B. Kagan, Bull. Soc. Chem. Fr. 1965, 1454; c) H. B. Kagan, N. Langlois, T. P. Dang, J. Organomet. Chem. 1975, 90, 353.

[11] M. J. Burk, T. G. P. Harper, J. R. Lee, C. Kalberg, Tetrahedron Lett. 1994, 35, 4963.

[12] M. J. Burk, J. G. Allen, W. F. Kiesman, J. Am. Chem. Soc. 1998, 120, 657.

[13] a) M. Kitamura, M. Yoshimura, M. Tsukamoto, R. Noyori, Enantiomer 1996, 1, 281; b) H.U. Blaser, C. Malan, B. Pugin, F. Spindler, H. Steiner, M. Studer, Adv. Synth. Catal. 2003, $345,103$.

[14] B. Heiser, E. A. Broger, Y. Crameri, Tetrahedron: Asymm. 1991, 2, 51.

[15] S. Krishnamurthy, Tetrahedron Lett. 1982, 23, 3315.

[16] J. E. Jeffery, F. Kerrigan, T. K. Miller, G. J. Smith, G. B. Tometzki, J. Chem. Soc. Perkin Trans. 1, 1996, 21, 2583. 